\title{
不安全操船状態評価の 海上交通流シミュレーションへの適用
}

安田 克*・井上欣三**

\section{Applicability of Unsafe Ship-handling Situation Index to Marine Traffic Simulation}

\author{
Masaru YASUDA, Kinzo INOUE
}

\begin{abstract}
The Unsafe Ship-handling situation(US) is known as a index that is able to estimate a potential risk of marine accident by calculating frequency of unsafe situation on maneuvering process. In our past study ${ }^{(1)(2)(3)}$, we were able to find out the correspondence between a marine accident and an US. Actually, it get to use this index in a planning of harbor, traffic route and so on.

However, due to neglect of maneuver's difference, it needs a lot of simulator experiments. In addition, in a real time simulator experiment, it has some limitations such as estimation area, target ship and so on.

In this study, we tried to apply traffic simulation to US. Since an US is calculate by a ship's motion (velocity, turn rate, lateral speed etc.) and maneuvering condition (rudder angle, engine motion, thruster etc.), we introduced MMG model to the traffic simulation. We tried to estimate a US by this traffic simulation and we were able to find out the correspondence between a marine accident and US just like the past study.
\end{abstract}

Keywords : Marine traffic engineering, Unsafe Ship handling situation, Marine accident, キーワード：海上交通工学、不安全操船状態、海難事故

\section{1.はじめに}

不安全操船状態（US：Unsafe Ship-handling situation）は、操船に対する衝突・乗揚の危険性を表 す指標である。国の航路整備計画や地方港湾の港湾 計画などにおいては、計画または整備に伴う船舶交 通の安全性を検討する一方で、その整備に係る費用 便益を計ることが求められていることもあり、現在 では、国の航路整備計画や港湾計画改訂に係わる検 討において安全性及び期待事故費用を計る目的で広 く利用されるようになった。

不安全操船状態を評価するには、操船シミュレー タ装置などにより操船者が実操船を行い、その操船 過程における舵、機関、タグ、スラスターなど操作
状態及び操船の結果として現れる速度、回頭角速度、 横流れ速度などの運動状態を抽出し、これを入力条 件として一定時間断面の予測航跡を推定して、その 予測航跡の他船、護岸、浅瀬などに対する衝突判定 の有無から不安全操船状態を検出する。

この場合、人間が操船することに伴う操船のばら つきをなくすため相当数の実験を行う必要がある一 方で、リアルタイムシミュレーションは実時間を要 するため、その実施ケースは極めて限られた条件、 範囲で行わざるを得なかった。著者らもこれまで来 島海峡航路をモデルとして操船シミュレータ実験に より不安全操船状態を評価し、海難発生位置や頻度 との対応(1)(2)(3)を試みたが、その対象範囲は最狭部に 
限り、船型も限定して行った。ある特定の条件に対 する操船の危険性を評価するうえでは、このような 手法は有効かつ適当なものと考えられるが、不特定 多数の船舶に対する評価としては限界がある。

そこで、本研究ではこのような問題を解決するた め、海上交通流シミュレーションにより交通流を再 現させ、これに不安全操船状態評価の適用を試みた。

\section{2. 不安全操船状態の概念}

Fig.1 に不安全操船状態の概念を示す。

不安全操船状態は、潜在的操船水域 ${ }^{(1)}$ (Potential Area of Water, PAW）の概念を導入し、時々刻々の操 作状態、運動状態から、現在の状態が継続した場合 の予測航跡を計算する。対象船舶のその時の状態に 忘じた最短停止時間（Short Stopping Time, SST）が、 他船や陸地、浅瀬に衝突するまでの余裕時間（Time To Collision, TTC) を超える場合に不安全操船状態と 判断される。

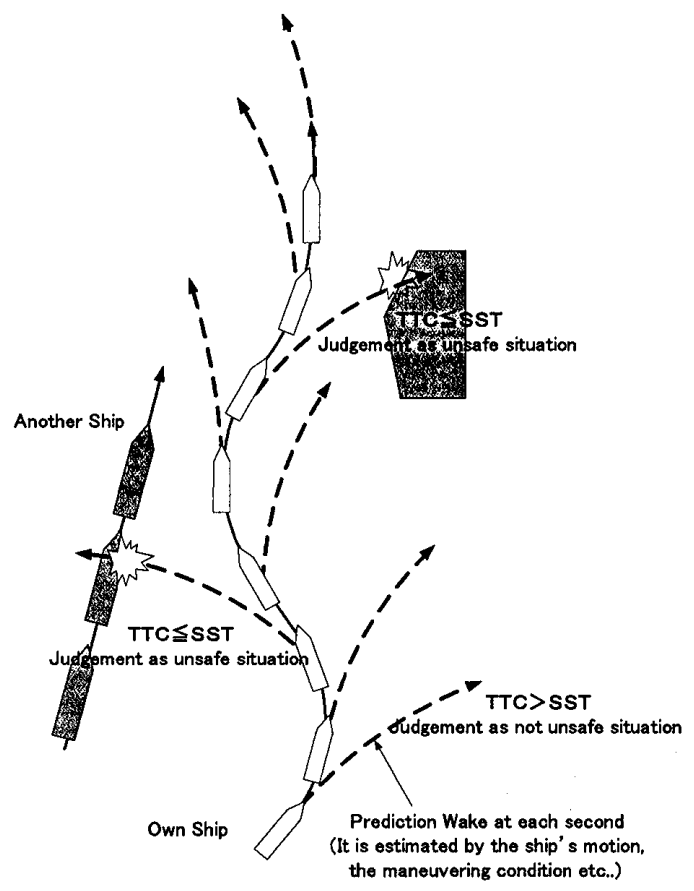

Fig.1 Concept of Unsafe Ship-handling situation

\section{3. 名古屋港における海上交通の再現} 3.1 運動モテルの導入

現状の海上交通流シミュレーションは、各ウェイ ポイント（変針点）で結ばれた経路を設定された速 力で移動する質点の動きであって、その間の船の操 作及び運動は考慮されていない。最近のシミュレー ションでは、TK モデルなどにより変針時の回頭を より現実に近づけたものもあるが、リアルタイムシ ミュレーションのように船の操作の結果として運動
を再現する海上交通流シミュレーションは、多大な 計算時間を要することと、全船の動きを運動モデル で再現するためには、様々な船の運動モデルデータ ベースが必要であることなどから汎用的ではなかっ た。

しかしながら、近年のコンピュータの計算速度は 目䝘るしく向上し、また、シミュレータによる検討 が主流となってきたことから、様々な種類の船の運 動モデルが蓄積されるようになり、海上交通流シミ ニレーションへの運動モデルの導入を可能にした。

運動モデルは、一般的な $\mathrm{MMG}$ モデル(4)(5)(6)を利用 し、入力条件は変針時及び避航時の変針角と速力と した。与えられた変針角に対する舵角は、オートパ イロット機能を利用し、原針路と目標針路との差及 びそのときの回頭角加速度、並行偏位量から変針に 必要な舵角量を求めた。また、機関は目標速力（ウ エイポイント間で設定された航行速力）になるよう なエンジン回転数を与え、所定の速力を得るように した。

\section{2 運動モデルよるる交通流の再現}

海上交通流シミュレーションによる交通流の再現 は、Fig.2 に示すように実態の船舶航行データから、 シミュレーション上、船舶が航行する通航経路をモ デル化し、各経路において発生する船舶の速力、隻 数などを実態データから設定する。シミュレーショ ンの実行では、各経路において設定された隻数に基 づき指数分布にしたがって乱数発生させたが、その 際、航行管制を踏まえ 20,000 トン以上(現状は 40,000 トン以上）の船舶の発生がある場合には、航路内で 500 トン以上の船舶と行き会わないよう発生時間を 遅らせるようにした。

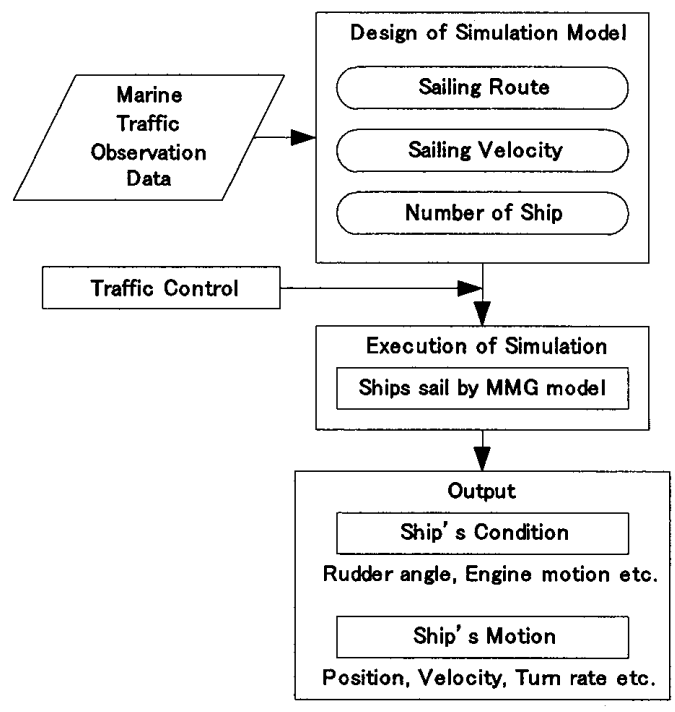

Fig.2 Flowchart of situation design 
（1）名古屋港における船舶交通実態データ

名古屋港の交通流を再現するにあたり、平成 10 年に名古屋港管理組合において実施された船舶交通 実態調査 ${ }^{(7)}$ による航跡データを利用した。船舶実態 調查は、名古屋港港域内を航行する船舶を対象に 2 日間にわたって実施されたものである。

\section{(2) 通航経路帯}

船舶航行実態調査による航跡データに基づき、船 型及び OD（O：Origin、D：Destination）などにより グループ化された通航経路帯を作成した。通航経路 帯はウェイポイント間を帯状の経路で結んだもので、 その幅はグループ化された航跡群の平均航跡位置か ら標準偏差の 2 倍 $( \pm 2 \sigma)$ を考慮した。また、その 間の通航速力は航跡群の平均速力とした。

(3) 交通流の再現

海上交通流シミュレーションによる再現は、航行 実態調查時の船型区分を踏まえ Table 1 に示すよう な 13 区分において計算した。

Table 1 Classification of Ship size

\begin{tabular}{|r|r|r|}
\hline$\sim 20 \mathrm{GT}$ & $500 \sim 1,000 \mathrm{GT}$ & $30,000 \sim 40,000 \mathrm{GT}$ \\
\hline $20 \sim 50 \mathrm{GT}$ & $1,000 \sim 5,000 \mathrm{GT}$ & $40,000 \sim 50,000 \mathrm{GT}$ \\
\hline $50 \sim 100 \mathrm{GT}$ & $5,000 \sim 10,000 \mathrm{GT}$ & Over $50,000 \mathrm{GT}$ \\
\hline $100 \sim 300 \mathrm{GT}$ & $10,000 \sim 20,000 \mathrm{GT}$ & \\
\hline $300 \sim 500 \mathrm{GT}$ & $20,000 \sim 30,000 \mathrm{GT}$ & \\
\hline
\end{tabular}

シミュレーションでは、1 日の時間変動を考慮し 48 時間を実施した。名古屋港は港の性質上、朝にラ ッシュ時閒帯があり、主要航路とする東航路では 6、 7 時頃にピークがあることがわかる。西航路では東 航路に見られるようなラッシュ時間帯は見られない。

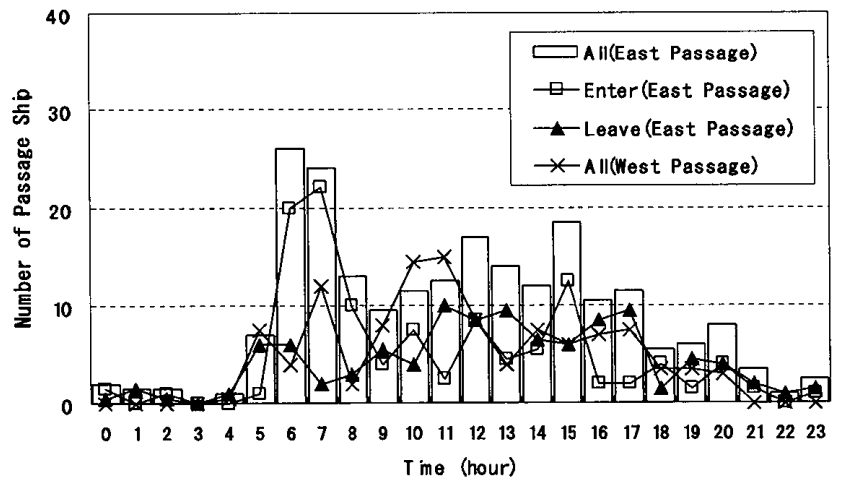

Fig.3 Number of passage ship on Higashi Route

Fig.4に実態調査により得られた 6 時から9時の輻 輳時間帯における 100 トン以上の航跡状況を示す。 また、Fig.5に運動モデルを導入した海上交通流シミ ユレーションによって再現した航跡状況を示す。
なお、20,000トン以上（現在は 40,000 トン）の管 制船が、航路内において管制対象船である 500 トン 末満の船舶と見合い関係となった場合には実情を踏 まえ管制船に優先権を与えるものとした。

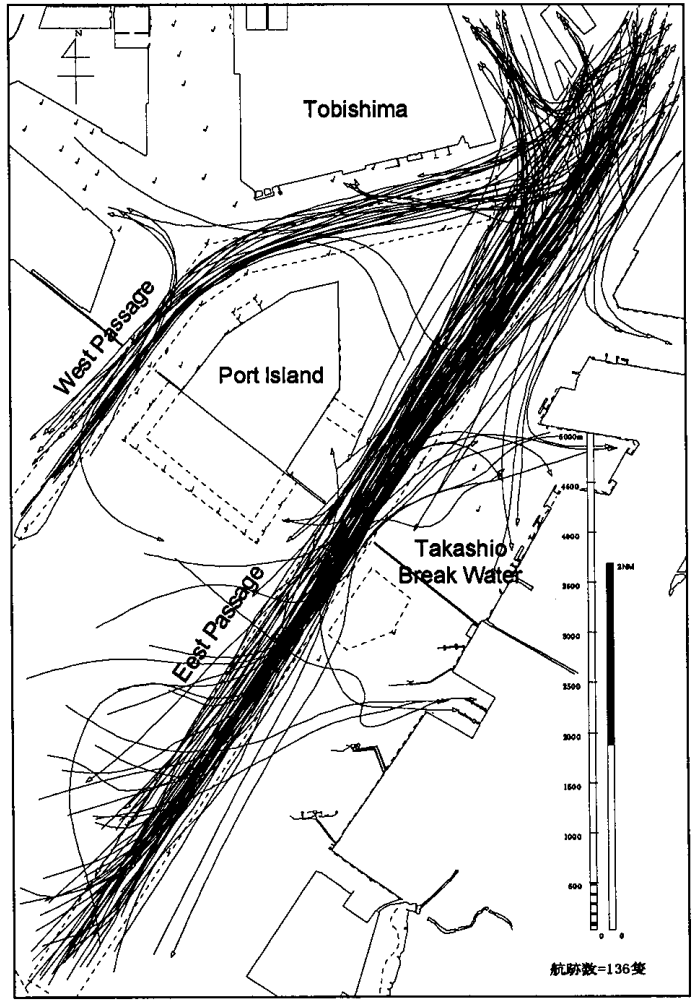

Fig.4 Actual Traffic Wake (6 9hr, above 100GT)

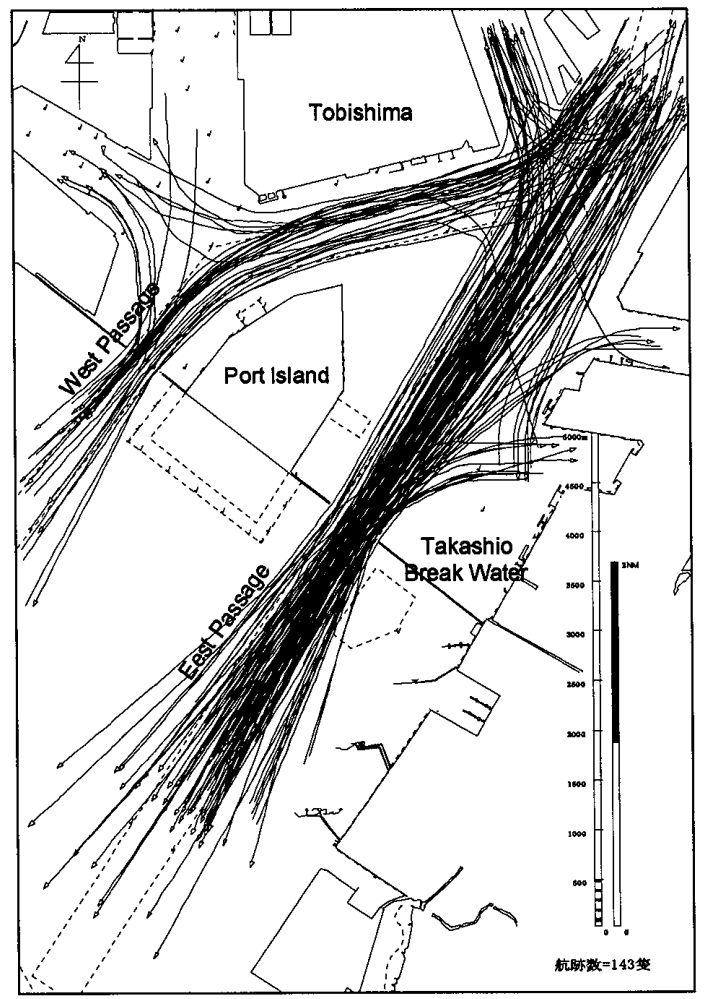

Fig.5 Simulation Traffic Wake (6 9hr, above 100GT) 


\section{4. 不安全操船状態評価の適用}

\section{1 不安全操船状態による操船危険性評価}

シミュレーションによって再現された各船に対し、 不安全操船状態を評価した。評価対象時間帯は、朝 のラッシュ時間帯を含む 6 時から 9 時とした。Fig.3 に示した実態航跡数より、名古屋港の主要航路であ る東航路では、朝のラッシュ時間帯に輻軖するよう すが見られるが、西航路においてはこのようなラッ シュはなく海難データとの対応を取るだけの十分な 航跡データが得られないことから、ここでは東航路 を出入りする 100 トン以上の船舶を評価対象とした。

Fig.6に 100 トン以上の入港船舶における不安全操 船状態を例として示す。また、Fig.7 は他船に対して 不安全操船状態となった場合の予測航跡が他船と衝 突した位置を示したものである。

名古屋港は、東航路を主航路として西航路及び北 航路から構成される。そして、これらは Fig.7 に示 すように金城水域で交差する。港則法では、その優 先順位は東航路、西航路、そして北航路の順に定め られているが、輻輇する時間帯においては船舶が頻 繁に合流・交差する危険な水域として知られている。

東航路を航行する船舶の不安全操船状態をみると、 各時間断面における操作状態と運動モデルから計算 された運動状態から推定される予測航跡は、Fig.7 の ように 3 航路が交差・合流する金城交差部で多く発 生していることがわかる。

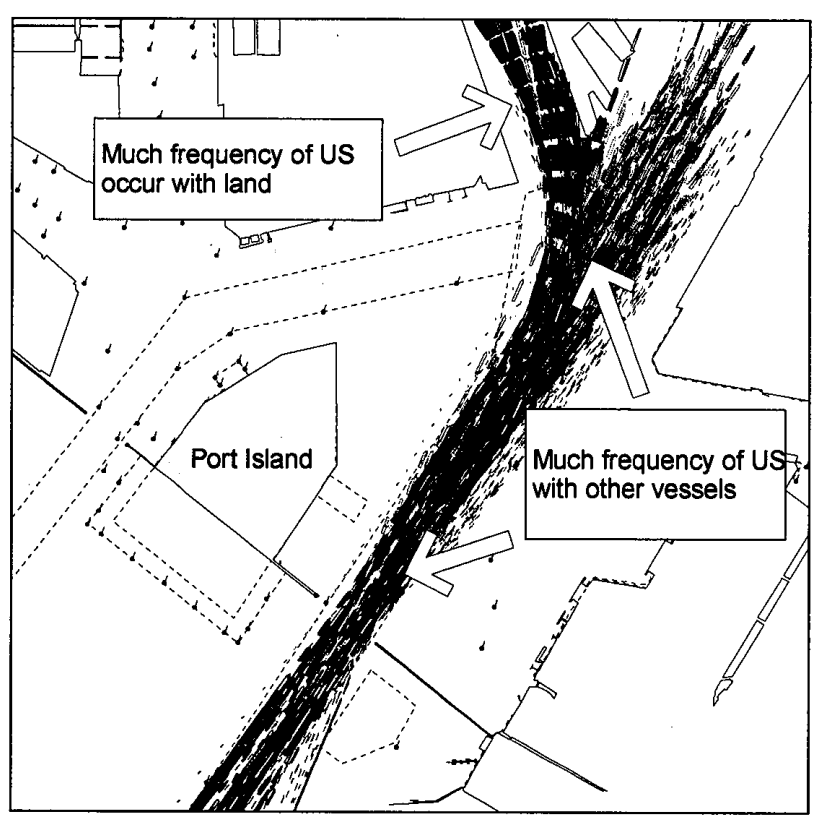

Fig.6 Occurrence Situation of US (100GT-)

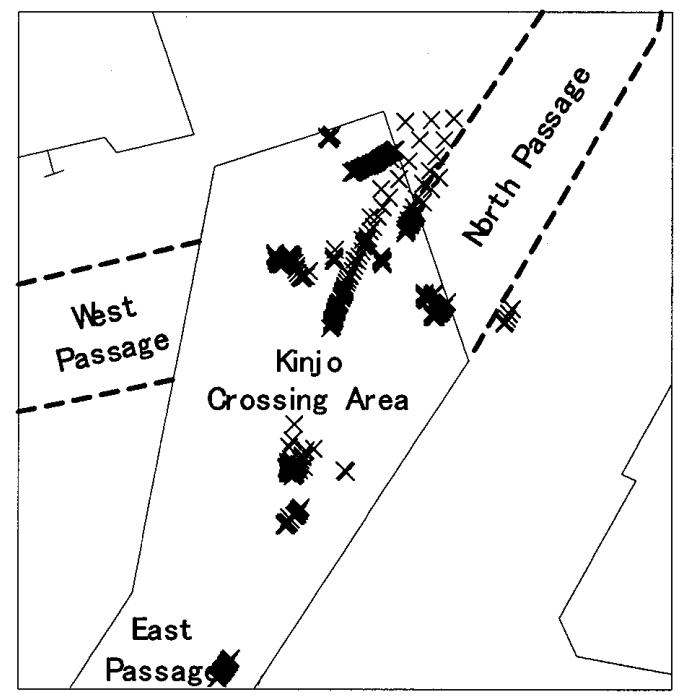

Fig.7 Relation with Passages in Nagoya Port

\section{2 名古屋港港域内における海難発生状況}

不安全操船状態と海難事故の対応をとるため、名 古屋港における海難発生状況について調查した。 Table 2 に過去 10 年間（1994 年〜2005 年）において 名古屋港港域内で発生した海難事故を示し、Fig.8に 海難位置を示す。名古屋港では過去 10 年間に 24 件 （40 隻）の海難事故が発生している。

本研究では、名古屋港の主航路である東航路を通 航して入出港した船舶を評価の対象としたため、海 難についても Fig.8 の点線で囲まれた東航路航行に 係るものに限定した。すなわち、西航路付近で発生 したものや港奥で発生した海難は対象外とした。し たがって、対象海難事故は Fig.8 の点線で囲まれた 11 件（19隻）とした。 
Table 2 Number of Accident in Nagoya Port

(1994-2005)

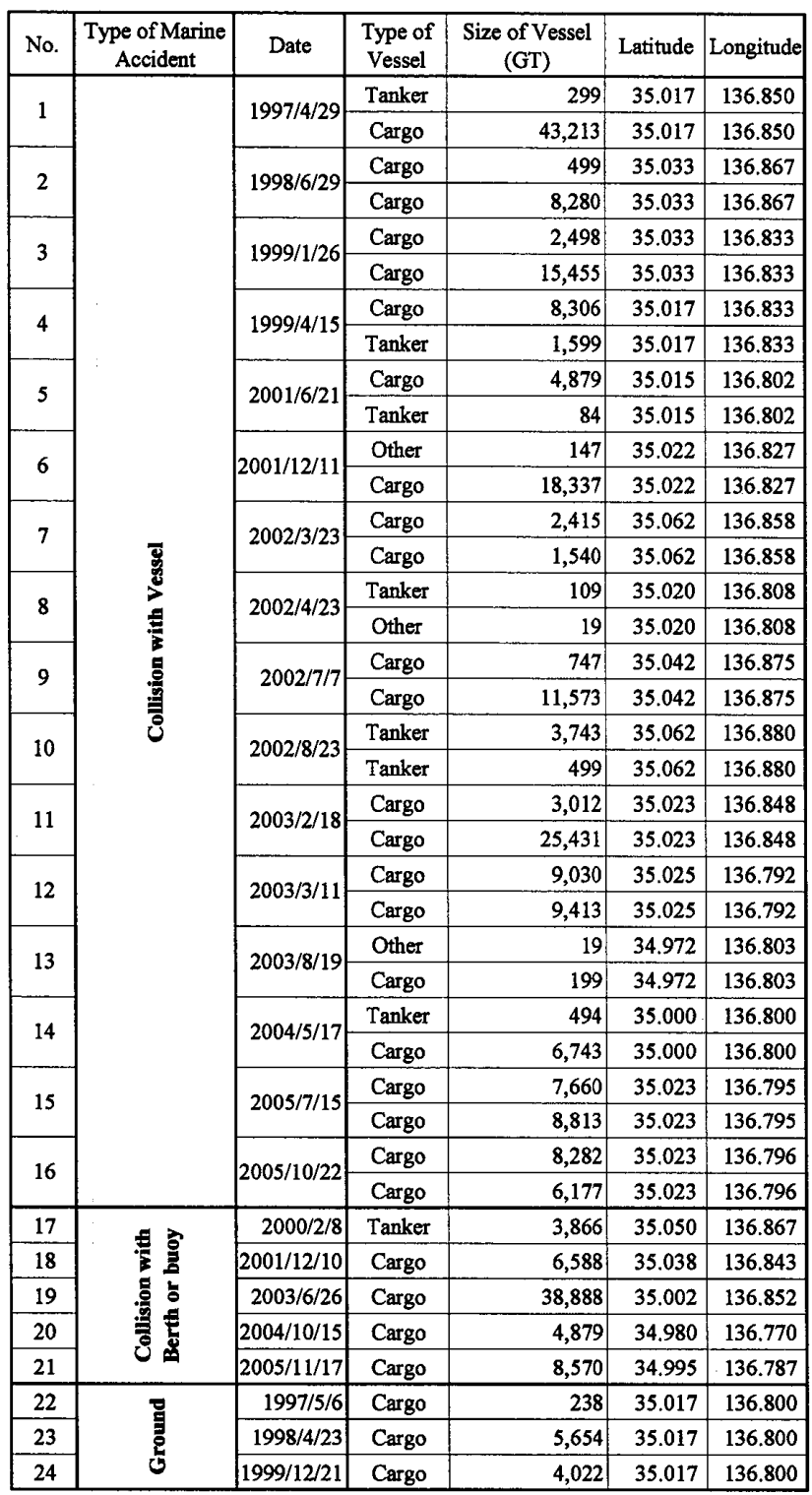

Offer : $4^{\text {th }}$ Regional Coast Guard Headquarters

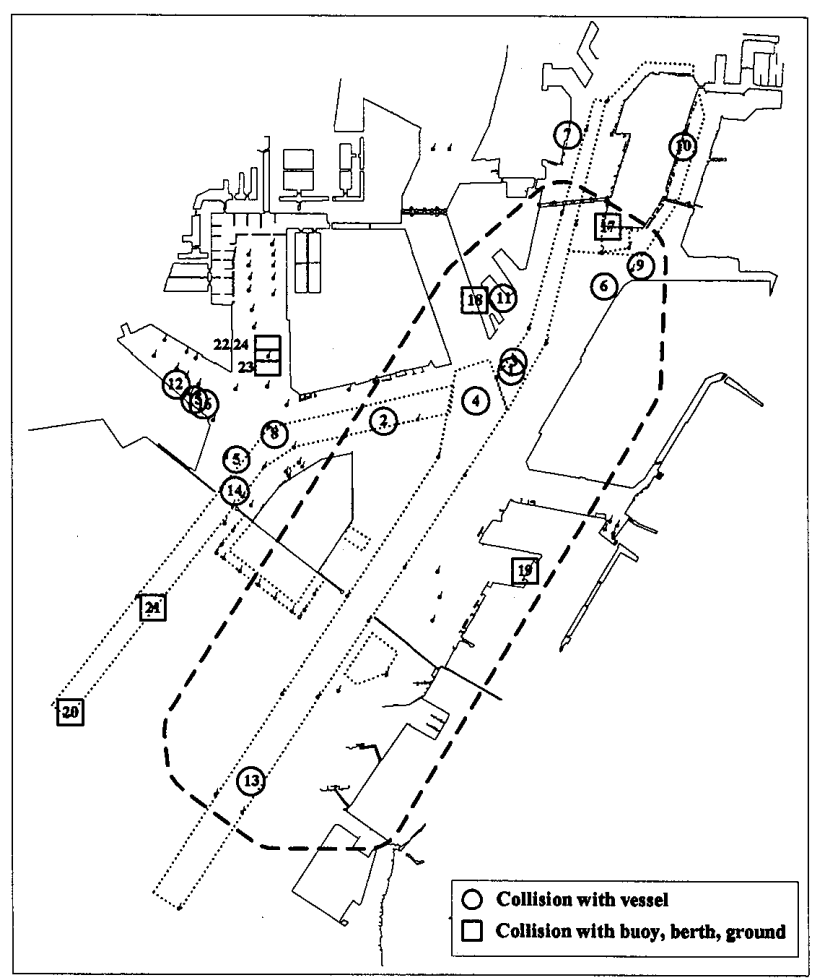

Fig.8 Marine Accident in Nagoya Port

\section{3 不安全操船状態と海難事故の対応}

\subsection{1 海難発生率}

海難発生率の推定にあたり、母数となる 10 年間の 通航隻数は、東航路を航行した 500 トン以上の年間 通航隻数（2004.7〜2005.6）を基淮とし、これを 10 倍して 10 年間の通航隻数と仮定した。

Table 3 に海難発生率を示す。年間の東航路通航隻 数データ（提供：名古屋港管理組合）の船型区分に したがい、各船型における海難隻数を整理した。こ の海難隻数を 10 年間の通航隻数で除して海難発生 率を求めた。

Table 3 Occurrence Ratio of Marine Accident

\begin{tabular}{|r|r|r|r|}
\hline $\begin{array}{c}\text { Type of } \\
\text { Vessel }\end{array}$ & $\begin{array}{c}\text { Number of } \\
\text { Marine Accident } \\
\text { (for 10 years) }\end{array}$ & $\begin{array}{c}\text { Number of Vessels } \\
\text { (for 10 years) }\end{array}$ & $\begin{array}{c}\text { Occurrence Ratio } \\
\text { of Marine Accident }\end{array}$ \\
\hline$-500 \mathrm{GT}$ & 5 & 102,590 & $4.874 \mathrm{E}-05$ \\
\hline$-5,000 \mathrm{GT}$ & 5 & 101,340 & $4.934 \mathrm{E}-05$ \\
\hline$-10,000 \mathrm{GT}$ & 3 & 32,240 & $9.305 \mathrm{E}-05$ \\
\hline $10,000 \mathrm{GT}-$ & 6 & 83,980 & $7.145 \mathrm{E}-05$ \\
\hline \hline Total & 19 & 320,150 & $5.935 \mathrm{E}-05$ \\
\hline
\end{tabular}

Offer : Nagoya Port Authority 


\subsection{2 不安全操船状態発生率との対応}

Fig.9に不安全操船状態発生率と海難発生率を示 す。図からわかるように不安全操船状態の発生率は、 船が大きくなるにつれ増加する傾向が見られる。ま た、海難事故率についても、10,000 トンまでの船型 においては、不安全操船状態と同様の増加傾向が見 られ、両者の間にはおおよそ $10^{-4}$ の一定の比の関係 が見られる。

海難事故は、10,000 以上の船型ではむしろ减少し ているが、このことは、名古屋港は強制水先区であ り、10,000トン以上の船舶においては、水先人の乗 船が義務付けられていること。また、東航路は名古 屋港海上交通センターによる管制水路があり、 20,000トン(現在は40,000トン)を超える大型船は、 管制船となることから、500 トン以上の船舶との行 き会いがないことなど、その航行に対し特別な安全 措置が取られている実情がある。

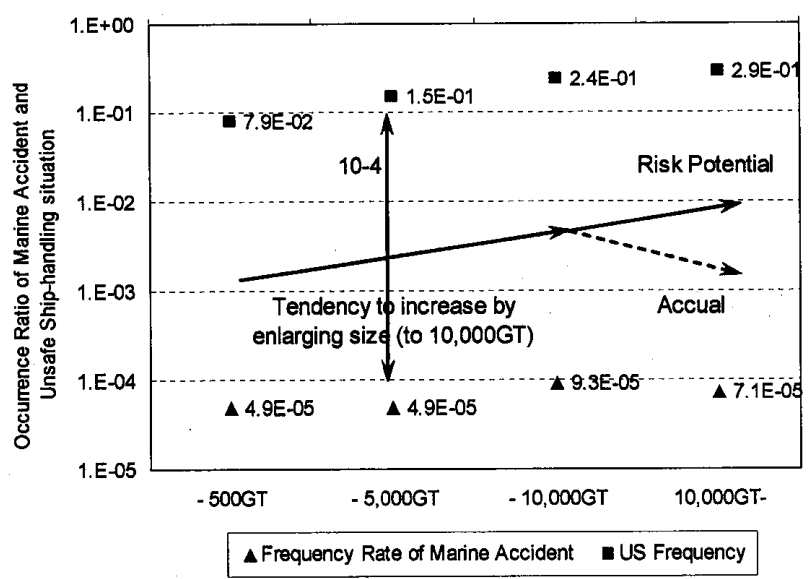

Fig.9 Correspondence between Marine Accident and Unsafe Ship-handling situation

\section{4 切迫レベルによる評価}

切迫レベル(2)を(1)式に示す。これは 0 から 1 の数 值で求めることができ、得られた值が 0 に近いほど

（すなわち、TTC $\fallingdotseq \mathrm{SST}$ ）、本船が止まることのでき る時間（SST）に極めて近いところで潜在的に衝突・ 乗揚危険があることを表し、危険を回避する余裕が 高いことを意味する。一方、数值が 1 に近いほど SST に対し TTC が小さく危険を回避する余裕が小さく、 危険に対する切迫レベルが高いことを意味する。

$$
\text { Emergency Level }=1-\frac{T T C}{S S T}
$$

Fig.10 から Fig.12 に入港時において不安全操船状 態となった場合の予測航跡が他船に衝突した位置と そのときの切迫レベルを示す。
Fig.10 に示す 500 トン未満の入港船では、高潮防 波堤を過ぎた付近で多く現れているが、その值は 0.2 〜0.4 である。つまり、高潮防波堤よりかなり手前 において避航操作した結果として、予測航跡が出港 船と衝突したものである。これは管制水路において 小型船が管制船と出会った場合、実情の運用を踏ま えシミュレーションでは小型船に避航義務を課して いる。小型船の大型船に対する避航操作の結果とし て不安全な状態が航路内で多く発生したもので、高 潮防波堤付近でその頻度が高く現れたのは、防波堤 通過に向けて航跡が収束し密になるためと考えられ る。

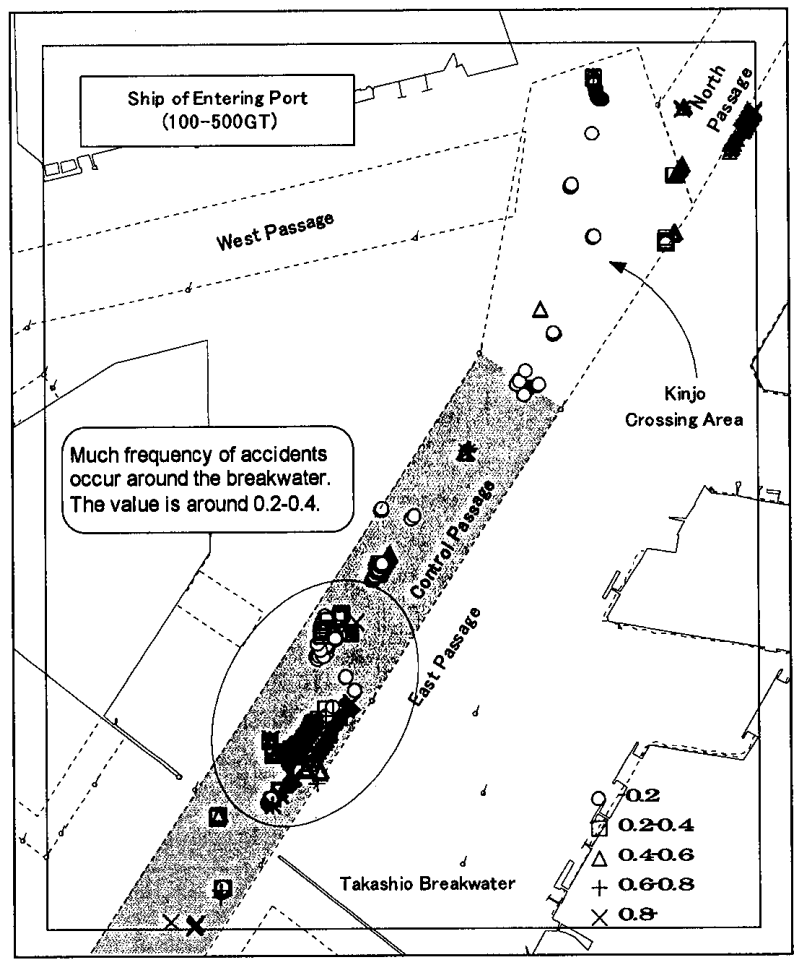

Fig.10 Collision Point of Prediction Wake and Emergency Level (100-500GT)

一方、Fig.11 及び Fig.12 みみと、船型が大型に なるほど金城交差部付近において多く発生し、切迫 レベルも比較して高い值を示している。500 トン以 上の船舶については、管制により大型船と行き会う ことがなく、管制船は小型船に避航義務を課したた め、500 トン未満の小型船で見られたような航路内 での行き会いによる不安全操船状態の発生は少ない。 ただし、管制航路を出て北航路方面、金城水路方面 への変針操船の過程において金城交差部付近で北航 路からの出港船、西航路からの入港船と交差・合流 することにより不安全操船状態が多く出現している。

名古屋港の航路のあり方を考える際、このような 航路内の行き会いにおける操船の危険性や金城交差 
部における交差・合流の危険性が常に指摘されるが、 こうした名古屋港の航路問題についても、この海上 交通流シミュレーションによる不安全操船状態では 反映している。

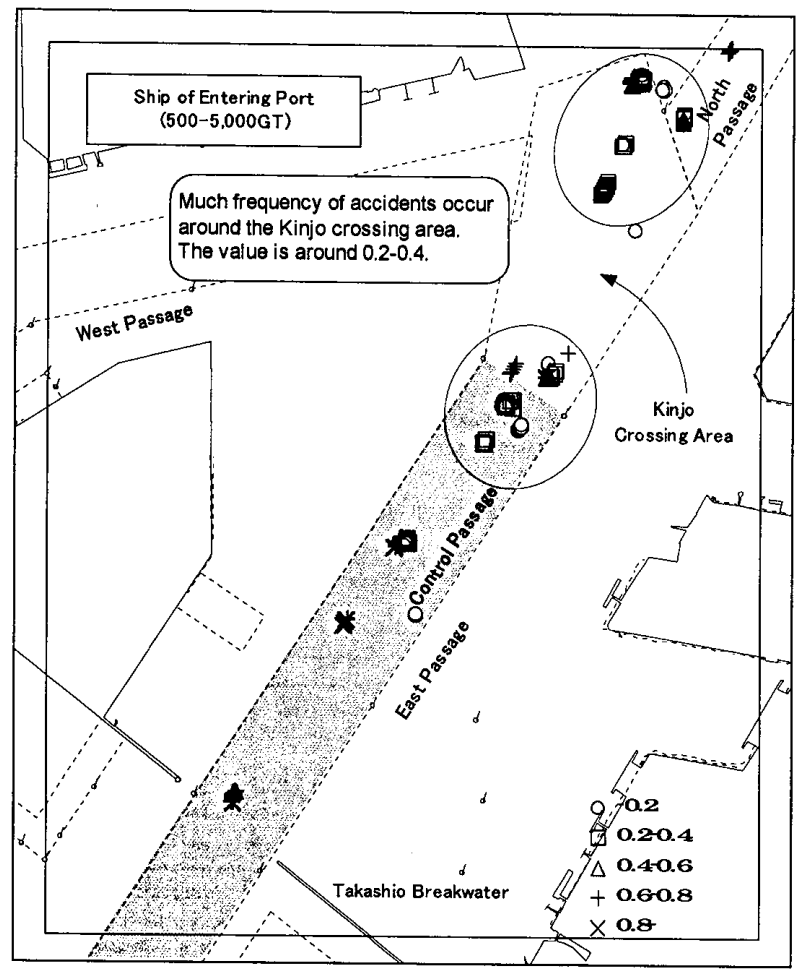

Fig.11 Collision Point of Prediction Wake and Emergency Level (500-5,000GT)

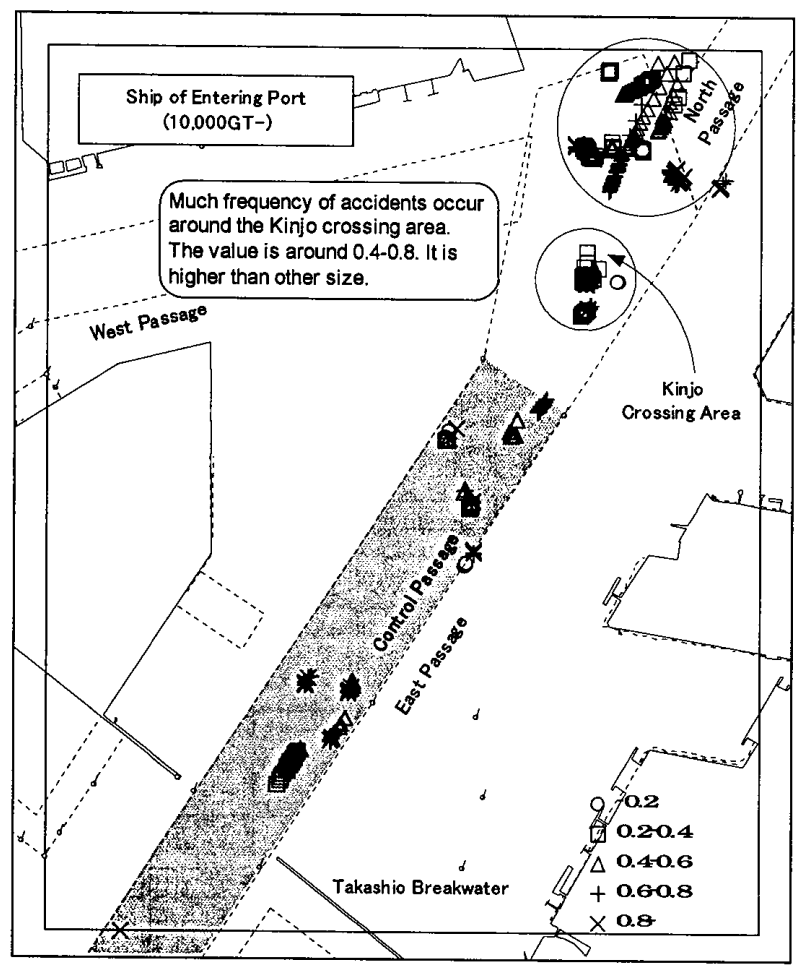

Fig.12 Collision Point of Prediction Wake and Emergency Level (5,000GT-)

\section{5. おわりに}

不安全操船状態の評価は、操船の危険性を表すこ とができる指標として広く利用されるようになって きた一方で、その評価には、操船シミュレータ実験 による実操船を伴い評価海域の規模、評価船の数、 検証パターンなどに制約をかけざるを得なかった。 もちろん、特定の条件に対する操船の危険性を評価 するうえでは十分であり適切な手法であるが、交通 流の場を評価するうえでは、操船者の違いによるば らつきを平滑化するため、相当数の実験を行う必要 があり限界があった。

本研究では、海上交通流シミュレーションによる 操船の危険性評価の適用の可能性を見出すことがで きた。これにより、操船シミュレータによる特定の 操船に対する危険性評価と海上交通流シミュレーシ ヨンによる交通流の場に対する危険性評価などのよ うに評価対象によって使い分けることが可能になる。 以下に本研究で確認できた事項を示す。

（1）海上交通流シミュレーションに運動モデルを 導入することにより、場に存在するすべての船 舶からの操船危険性の評価が可能になった。

（2）海上交通流シミュレーションでは、一定の避航 モデルのもとで操船するため、航行環境の変化 に伴う船舶交通や護岸、浅瀨等への潜在的乗揚 衝突危険性の違いをより明確に表すことがで きるようになった。ただし、海上交通流シミュ レーションの避航操船方法には、船の大きさは 考慮されているが、操繸性の違いまでは考慮さ れていない。したがって、今後は操縦性を考慮 した変針・避航操船方法のあり方について研究 を進める必要がある。

（3）海難事故率との関連性についても $10^{-4}$ の比で 対応が取れることが確認でき、より合理的な方 法でハインリッヒの法則との対応を取ること ができた。

なお、本研究では外力条件は考慮しなかったが、 運動モデルを取り入れたことにより、外力条件を加 味した再現が可能になる 


\section{参考文献}

（1）井上欣三，川瀬雅勇己, 安田 克, 臼井英夫, 世良 亘, 瀬田広明, 朴 栄守, 原 大地, 広 野康平, 増田憲司 : 不安全操船状態を指標とす る操船の安全性評価モデル,関西造船協会論文 集,第 241 号,pp.205-210,2004.3

（2）安田 克, 井上欣三, 臼井英夫, 広野康平 : 来 島海峡航路における不安全操船状態の発生傾向 と海難発生傾向との対応, 日本航海学会論文集, 第 113 号,pp.37-41,2005.9

（3）安田 克, 井上欣三, 臼井英夫, 冨久尾義孝： 来島海峡航路における乗揚海難発生率と不安全 操船状態発生頻度との対応について,日本航海 学会論文集,第 114,pp.25-30,2006.3

（4）日本造船学会 : 第 3 回操縦性シンポジウム,昭和 56 年 12 月

（5）日本造船学会：操縦性研究の設計への応用一運 動性能研究委員会 第 12 回シンポジウムー,平 成 7 年 12 月

(6) 本田啓之輔：操船通論（六訂版）,成山堂,2001.9

（7）名古屋港管理組合,基本計画調査（名古屋港航路 体系調查（現況調查），平成 11 年 3 月 